\title{
The Late Weichselian and Holocene shoreline displacement on the west-central coast of Svalbard
}

\author{
JON Y. LANDVIK, JAN MANGERUD \& OTTO SALVIGSEN
}

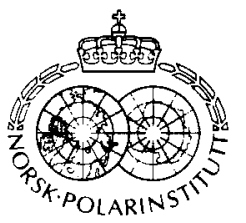

Landvik, J.Y., Mangerud, J. \& Salvigsen, O. 1987: The Late Weichselian and Holocene shoreline displacement on the west-central coast of Svalbard. Polar Research 5 n.s. . 29-44.

\begin{abstract}
Three well-developed raised marine shorelines along Nordenskiöldkysten have been studied and correlated with the shoreline displacement since the last deglaciation. The marine limit of $64 \mathrm{~m}$ in the area is of Late Weichselian age and has been dated to 10,900-11,000 years B.P. An intermediate level at $50 \mathrm{~m}$ is estimated to be $10,600-10,000$ years old and demonstrates a sea level stagnation probably caused by a glacier readvance in eastern Svalbard during the Younger Dryas. A Holocene transgression culminating shortly after 6,000 years B.P. has been stratigraphically demonstrated, and it probably correlates with the Tapes transgression of Scandinavia. No pre-Late Weichselian marine levels are found, and the large rebound can be attributed only to a Late Weichselian glaciation.
\end{abstract}

Jon Y. Landvik \& Jan Mangerud, Department of Geology, Section B, University of Bergen, Allégt. 4l, N-5007 Bergen, Norway; Otto Salvigsen. Norsk Polarinstitutt, Rolfstangveien I2, N-1330 Oslo Lufthavn, Norway; October 1986 (revised January 1987).

In the discussion on the extension and timing of the Late Weichselian ice sheet in the Barents Sea and Svalbard area (Andersen 1981; Elverhøi \& Solheim 1983), the shoreline displacement studies have been very important. The pattern of isobases (Schytt et al. 1968; Boulton et al. 1982), the occurrence of more than $100 \mathrm{~m}$ of Holocene rebound on Kong Karls Land (Salvigsen 1981), and the geology of the sea bed east of Svalbard (Elverhøi \& Solheim 1983), suggest that an ice sheet existed at least in the northern Barents Sea during the Late Weichselian. Due to a sparse terrestrial record, however, the extension of the ice sheet over the Svalbard archipelago and especially over Spitsbergen has been debated (Troitsky et al. 1979; Boulton 1979; Boulton et al. 1982; Salvigsen \& Nydal 1981; Miller 1982; Mangerud \& Salvigsen 1984; Mangerud et al. 1984).

The best evidences for coverage by glacier ice of most of the archipelago, and certainly the area described in this paper, are the moraine lobes (Ohta 1982) in the submarine extensions of Kongsfjorden and Isfjorden in the sea west of Spitsbergen. Stratigraphic evidence shows that the lobes are probably of pre-Weichselian age because Kongsfjorden was not filled with glaciers since the Early Weichselian or earlier (Miller 1982; Forman \& Miller 1984).
The area along the long fjords, Isfjorden and Van Mijenfjorden, is one of the key areas for the study of the western extension of the Barents Sea Ice-sheet, and the relation between this and local ice domes on Spitsbergen. Consequently, a cooperative project between the Norwegian Polar Research Institute and the University of Bergen was started dealing with the Quaternary stratigraphy, glacial geology, shorelines, etc., in that area. In addition to published information the following data exist: a shoreline displacement curve from Agardhdalen on the east coast (Mangerud \& Salvigsen, unpublished), a curve from outer Isfjorden (Sandahl 1986) and results from Elgersma \& Helliksen (1986) who studied the entire Van Mijenfjorden area with respect to sea level history.

The present paper will present the westernmost shoreline displacement curve of this fjord transect area, and we will discuss the direction of the isobases along the west coast.

Most of the elevations have been levelled, and the mean tide has been used as a basis for levelling, as well as for measurements by Paulin altimeter. The accuracy in the determination of mean tide level depended much on the duration of our stay in each locality. However, the geological significance of such inaccuracies is minor 
compared to the uncertainty in both determining the exact altitudes and dating the past sea levels in this area. Radiocarbon dates were carried out at the Laboratory for Radiological Dating in Trondheim. The stratigraphical nomenclature follows Mangerud et al. (1974), but the beginning of the Late Weichselian is set at 25,000 years B.P. (Mangerud \& Berglund 1978).

\section{Shorelines between Isfjorden and Bellsund}

The $40 \mathrm{~km}$-long Nordenskiöldkysten strandflat lies between Isfjorden and Bellsund (Figs. 1 and 2). On land, the strandflat plain is up to $12 \mathrm{~km}$ wide, and it continues at shallow depth several kilometres to the west. To the east it terminates

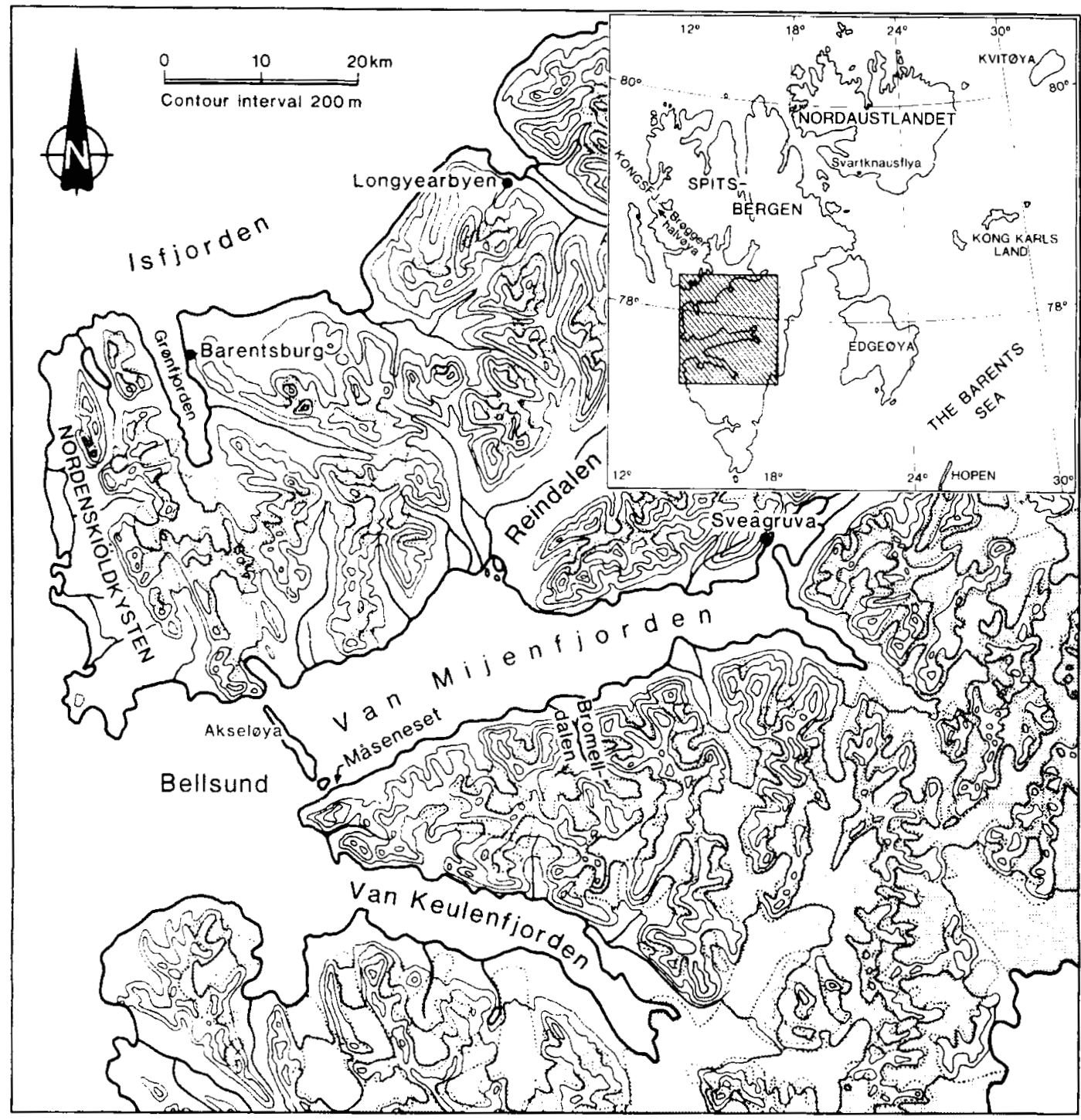

Fig. I. Map of west-central Spitsbergen showing the main topography and distribution of present-day glaciers (shaded). Inset map of Svalbard. 
abruptly at 60 to $100 \mathrm{~m}$ a.s.l. against the mountain range. Starting from the north, the Griegdalen, Tjørnskardet, Orustdalen and Ytterdalen valleys (Fig. 4) cut the mountain range. The heads of both Orustdalen and Ytterdalen are occupied by glaciers.

The strandflat is cut into metamorphic rocks of Late Precambrian (Hecla Hoek) age (Hjelle et al. 1986). Extensive well-developed shorelines and alluvial fans are developed in a discontinuous veneer of Quaternary sediments. Talus terraces, a type of rock glacier (Liestøl 1962), are found along the mountain sides.

Direct evidences of glaciation are few. There are no moraines, and only a restricted till cover in Folddalen is found (see below). However, well preserved glacial striae (Fig. 4) demonstrate that ice lobes once came out the Ytterdalen, Orustdalen and Linnédalen valleys. Considering the intensive weathering in this area the striae are most probably of Late Weichselian age.

Along Nordenskiöldkysten a distinct pattern of three well developed shorelines, with numerous intermediate, less continuous shorelines, occurs (Figs. 2 and 3). We denote the distinct lines as informal morphostratigraphical units, beach levels A, B and C, which for convenience also refer to the corresponding sea levels.

The three levels have been traced on aerial photographs and plotted on the map (Fig. 4) by use of a sketch master. Due to the inaccurate contours on the topographic map, the nearly

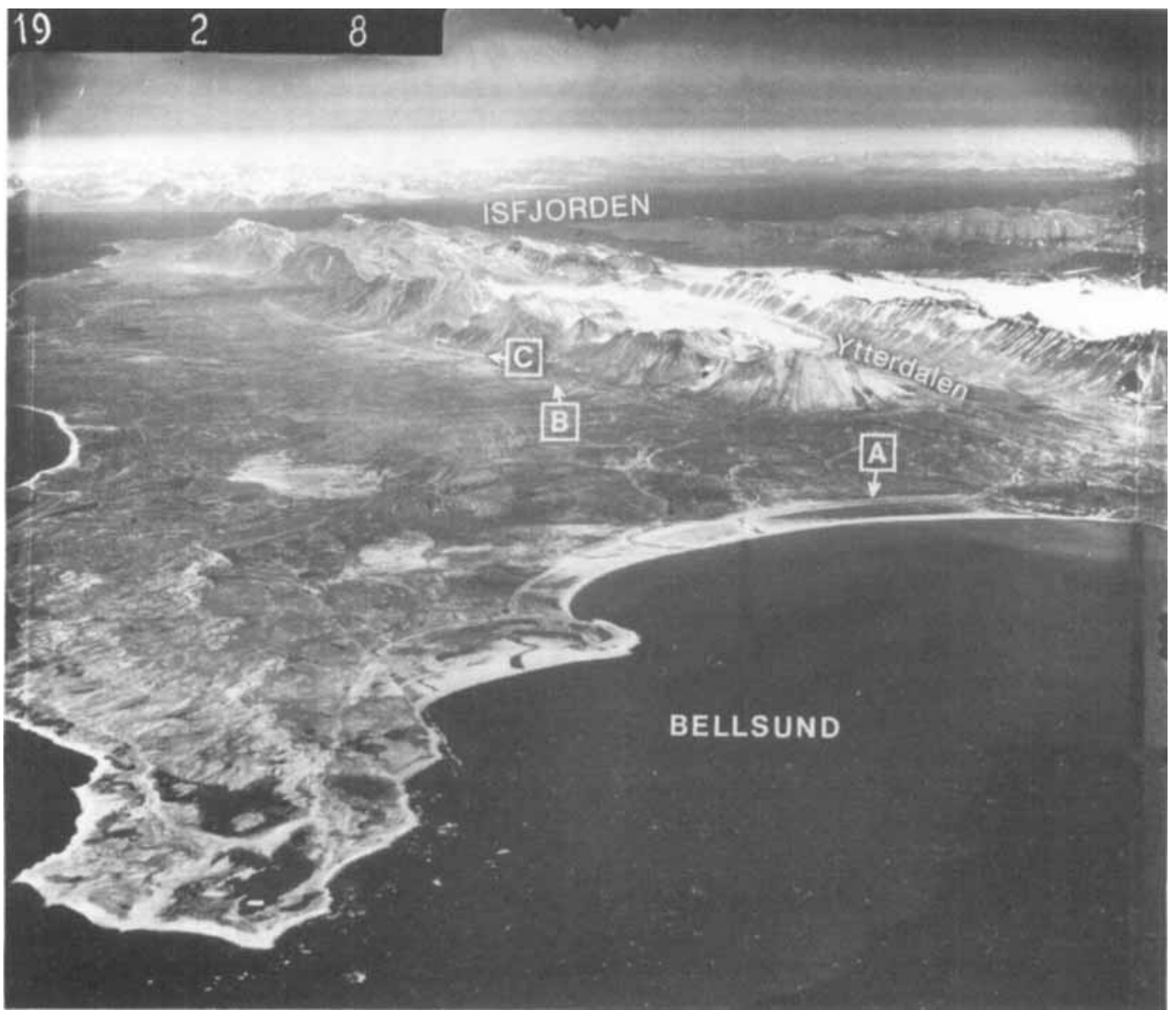

Fig. 2. Oblique air photo of Nordenskiöldkysten seen from Bellsund. The three beach levels A, B and C are marked. Photo: Norsk Polarinstitutt S 361928. 
horizontal shorelines appear to cross the contours several times (see beach level B, Fig. 4). In general, all three levels are dominated by low 40 to $80 \mathrm{~m}$ wide beach ridges, which are locally replaced by wave-cut cliffs and accumulation terraces. The cliffs are restricted mostly to the uppermost terrace.

We interpret beach level $C$ to be the Late Weichselian marine limit in the area. More detailed field investigations have been carried out near the mouths of Orustdalen and Ytterdalen (Fig. 4).

\section{Beach level C}

Along Nordenskiöldkysten, close to the upper break of the strandflat, beach level $\mathrm{C}$ is a discontinuous 50 to $100 \mathrm{~m}$ wide beach ridge at $64 \mathrm{~m}$ a.s.l, varying within a couple of metres. The ridge generally consists of sandy, rounded gravel with a concentration of cobbles and small boulders at the surface. Except around the mouth of the valleys, level $\mathrm{C}$ is at the highest elevation a shoreline can be preserved, simply because the slope is too steep above this level and dominated by slope processes. Only in Linnédalen have we found any evidence of a higher sea level (Mangerud et al. 1985), but Sandahl (1986) demonstrated that the shoreline was later overridden by ice. The proximity to the steep mountain slope has caused considerable destruction of beach level $\mathrm{C}$ by subsequent stream erosion and slope processes, but all the mapped level $\mathrm{C}$ deposits are assumed to represent a contemporaneously formed shoreline. Several sites along this level will be described below.

\section{Folddalen}

Where the tributary valley Folddalen enters Ytterdalen (Fig. 4) there is a $1.5 \mathrm{~km}$ long and 120 $\mathrm{m}$ wide well-developed marine terrace with 5 or 6 minor parallel beach ridges on the surface. The surface itself is covered with very coarse grained

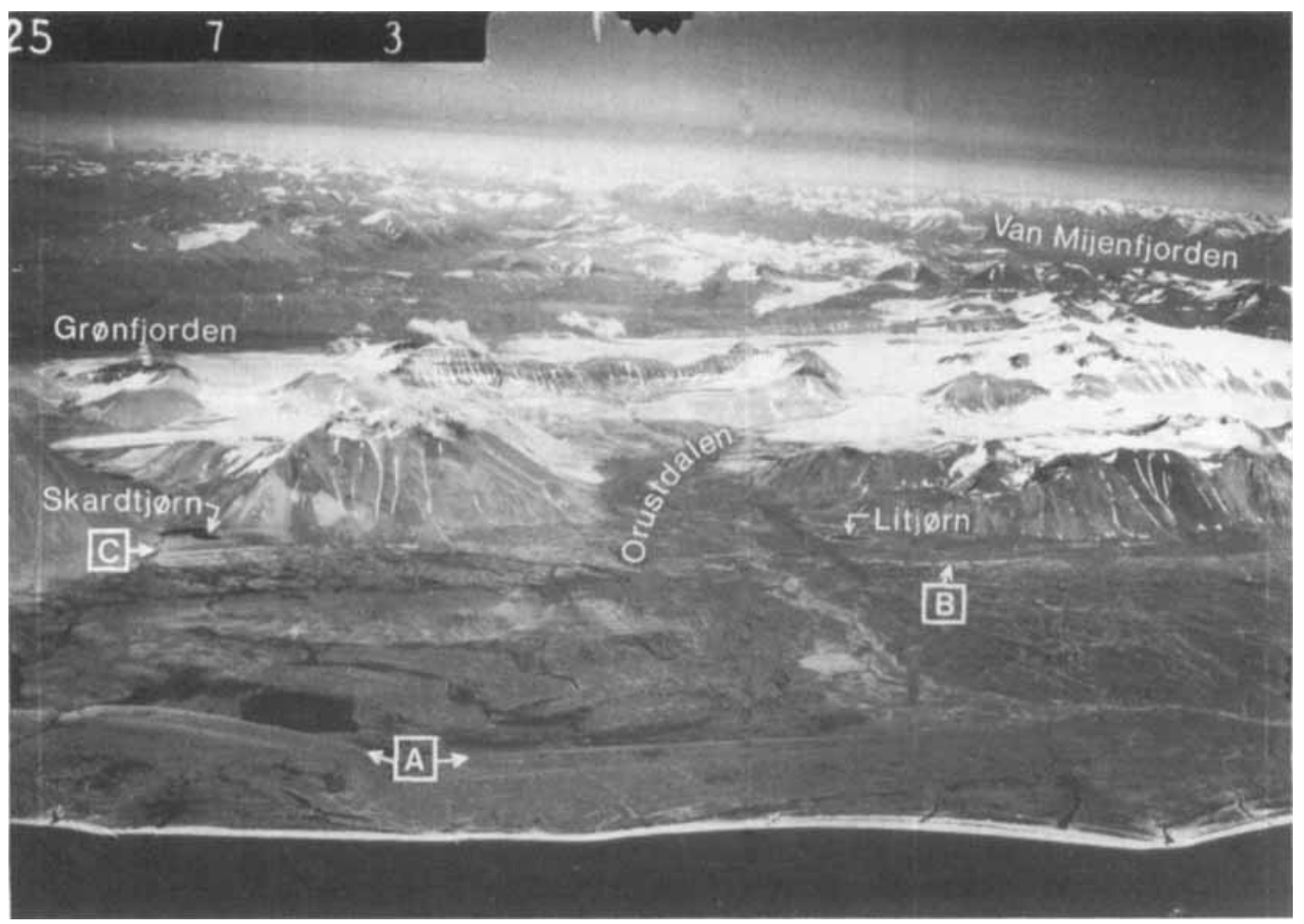

Fig. 3. Oblique air photo of Nordenskiöldkysten with, from the left, Tjornskardet and Orustdalen. The three beach levels are marked. Photo: Norsk Polarinstitutt \$36 2573. 
Fig. 4. Map from Nordenskiöldkysten showing the distribution of the postglacial beach levels A, B and $C$. For location see Fig. 1.

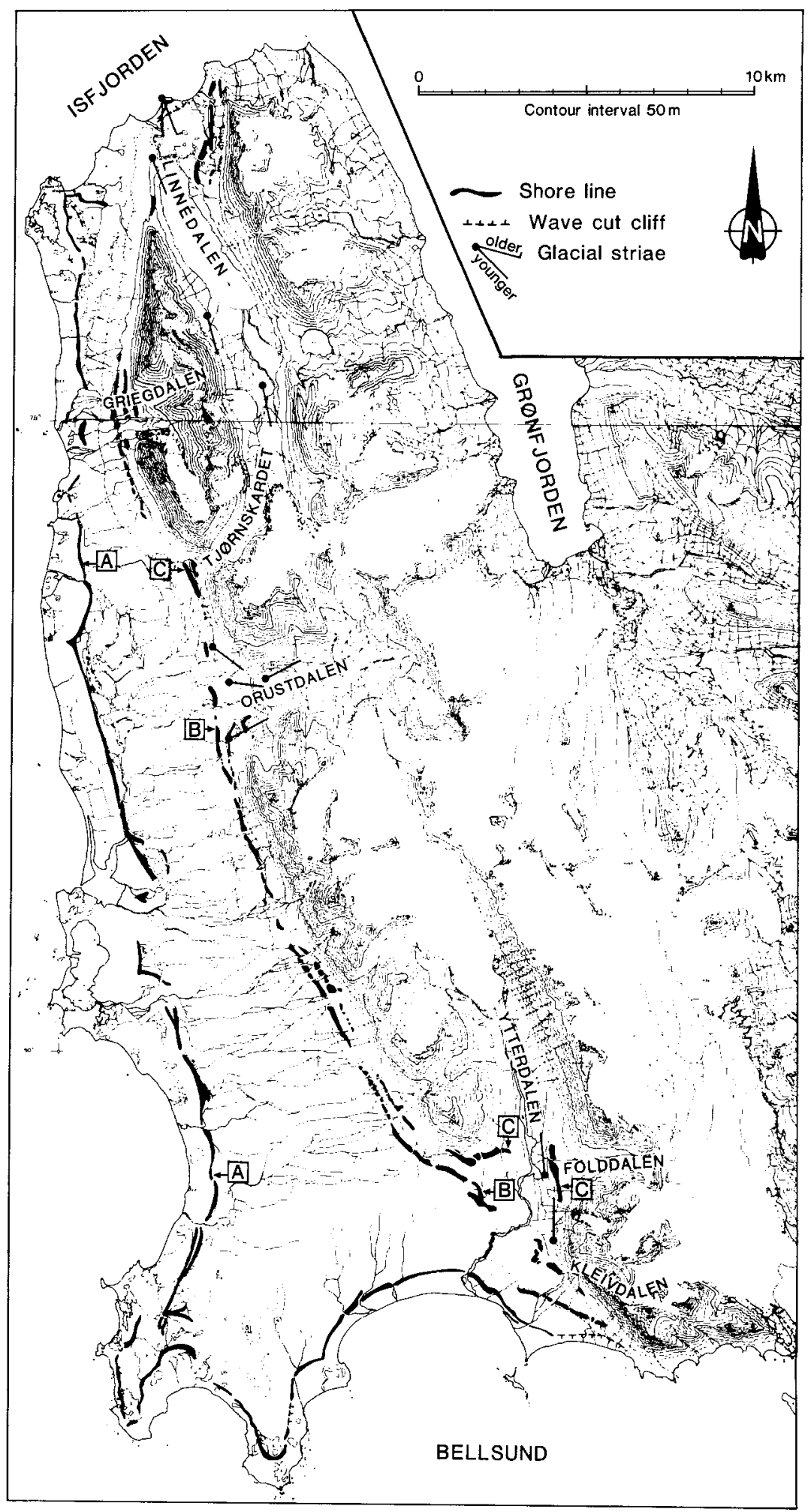


sediments, rounded cobbles and boulders, mainly derived from the local quartzite. For a distance of $300 \mathrm{~m}$ the terrace terminates against a $5 \mathrm{~m}$ high cliff cut into bedrock at $64.6 \mathrm{~m}$ a.s.l. (Fig. 5). To the south, this cliff is replaced by a gently sloping beach ridge rising to $69.4 \mathrm{~m}$ a.s.l. (Fig. 5). No marine features are found at higher elevations, even though the area has a low relief and slope processes are less active. However, some scattered sub-angular to rounded quartzitic cobbles and boulders, presumably of littoral origin, lie on the slope to the east of the main terrace. These and other erratic clasts are concentrated in small transverse belts on a north to south trending dolomite ridge, and they are interpreted to be remnants of a till cover which was deposited by a glacier in Ytterdalen and thus not an in situ marine deposit.

Shells from sediments in the bank exposure, that was correlated with the main terrace of level $C$, yielded radiocarbon dates of $11,020 \pm 110$ years B.P. (T-4865) and $10,840 \pm 110$ years B.P. (T-5995) (Fig. 6). On the southern bank, the river cuts through the main terrace at $64 \mathrm{~m}$ a.s.l. and through another terrace $56 \mathrm{~m}$ a.s.l. (Fig. 6). Between the two terraces the surface slopes towards the river and is dominated by subrecent solifluction features. To the north of the river there is a continuous slope in front of the $64 \mathrm{~m}$ a.s.l. terrace, and there is no distinct level at $56 \mathrm{~m}$ a.s.l. which supports the assumption that the 56 $\mathrm{m}$ terrace on the southern side is an erosional remnant of one formerly more extensive deposit. The $11,020 \pm 110$ years B.P. date was obtained from shell fragments collected on the surface sloping towards the river (Fig. 6), $51 \mathrm{~m}$ a.s.l. For a more precise interpretation, the site was revisited, and a $2.5 \mathrm{~m}$ deep pit was excavated near the top of the $56 \mathrm{~m}$ terrace (Fig. 6). The sequence, from bottom to top, is:

1) gravelly sand with scattered shell fragments and soft sediment deformation structures, erosionally truncated and covered by 2) a thin finegrained sand bed with current ripples showing transport towards WNW. This bed is overlain by 3) a gravelly coarse-grained sand interpreted as an erosional lag and enriched in shell fragments of Mya truncata and Hiatella arctica, dated to $10,840 \pm 110$ years B.P. Amino acid analyses of 13 of the shell fragments yielded a mean of alle/ Ile (total) of $0.018 \pm 0.004$ (one standard deviation) and no detectable epimerization in the free fraction. The analyses suggest that the fragments are of the same age. The upper $1 \mathrm{~m}$ of the terrace comprises a gravelly cobbly beach sediment.

The shell fragments stratigraphically underlie, and must be as old or older than the $56 \mathrm{~m}$ a.s.l. terrace. As discussed above, the field observa-
Fig. 5. Levelled profiles across the marine limit terraces (beach level $C$ ) at Folddalen (FF') and west (YY) of the mouth of Ytterdalen. Profile FF is laterally displaced $100 \mathrm{~m}$ at the wave-cut cliff. Circles show beach gravel at the surface.

Fig. 6. A cross section of beach $C(64 \mathrm{~m}$ a.s.1.) and its assumed continuation in Ytterdalen. The dates indicated are on shell fragments in sediments interpreted to be distal and contemporaneous to beach $C$.
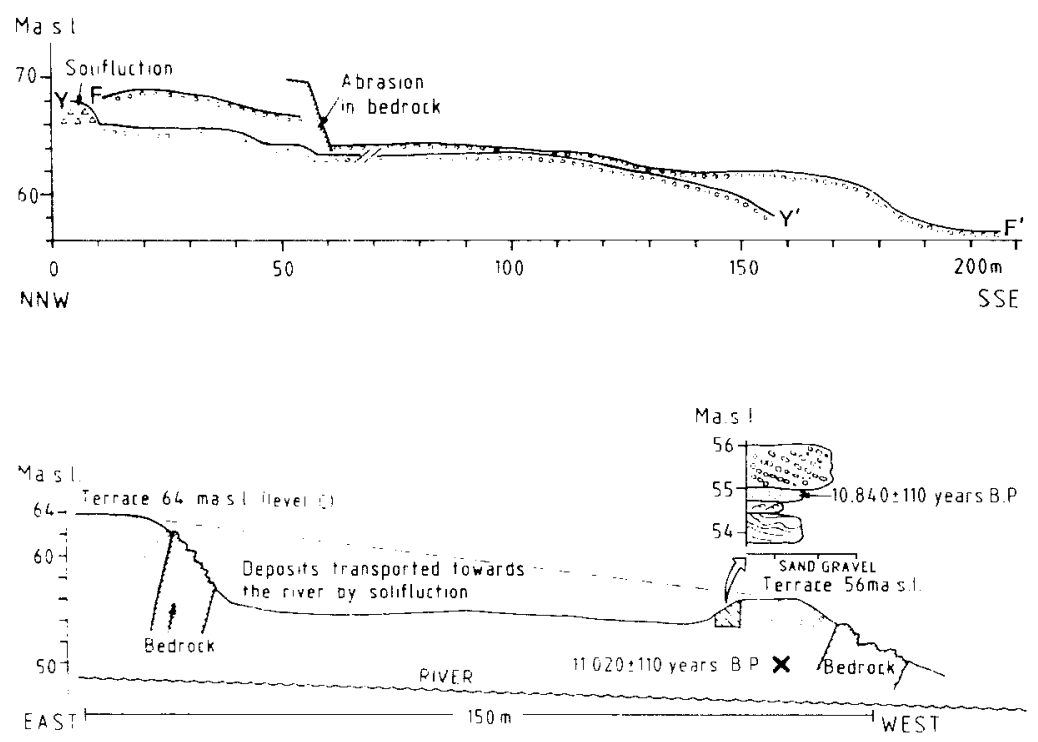
tions suggest that the $56 \mathrm{~m}$ and the $64 \mathrm{~m}$ terraces both were formed as parts of a formerly more continuous deposit. With this interpretation, the shells give an age of 11,000 years for the sublittoral deposits corresponding with the $64 \mathrm{~m}$ a.s.l. marine limit.

\section{West of Ytterdalen}

At the southern end of the mountain range, the shoreline $\mathrm{C}$ along the western foothill curves to the east into the wide mouth of Ytterdalen, where it terminates (Fig. 4). As the shoreline is some distance from the mountain side, it is well preserved here. Slightly above the main level, there are remnants of a $30 \mathrm{~m}$ wide terrace overridden by a solifluction lobe at $66.1 \mathrm{~m}$ a.s.l. (Fig. 5). Below this terrace lies the main terrace at $64.1 \mathrm{~m}$ a.s.l., which is 60 to $70 \mathrm{~m}$ wide and has a $40 \mathrm{~m}$ wide, and $0.5 \mathrm{~m}$ high beach ridge proximal to the front slope (Fig. 5). One km farther east the uppermost level is missing, and the wide main terrace ends against a wave-cut cliff at $63.6 \mathrm{~m}$ a.s.l. The terrace slopes gently about $5 \mathrm{~m}$ towards a well developed proximal break. Terraces and beach ridges are vegetation covered and are composed of sandy gravel with some increase in cobbles at the surface. Only a few very small shell fragments were found in the deposits.

\section{Orustdalen}

Well preserved glacial striae occur within, as well as immediately outside Orustdalen (Figs. 3 and 4). South of the mouth of the valley (west of Litjørna), striated roches moutonnées strewn with erratic quartzite boulders (Fig. 7) occur immediately above the uppermost beach ridge. Marine wave action would have removed the striae and erratics, and therefore the beach ridge must represent the post glacial marine limit at the site.

Shells of Mya truncata and Hiatella arctica are frequent in sediments along the river in the lower parts of Orustdalen. One sample was collected about $2.5 \mathrm{~km}$ from the present glacier front; the shells had been washed out of a marine silt in the river bed. They were dated to $10.240 \pm 70$ years B.P. (T-4943), which represents the age of an unknown shorelevel considerably higher than the $30 \mathrm{~m}$ altitude of the dated collection. More importantly the date reveals that the central part of Orustdalen was deglaciated prior to 10,200 B.P.

\section{Skardtjørna}

Lake Skardtjørna, at the western end of Tjørnskardet (Figs. 3 and 4), is dammed by a $65 \mathrm{~m}$ a.s.l. (Paulin altimeter) beach ridge which crosses the valley (Fig. 8) and has large well-rounded quartzite cobbles at the surface.

Several smaller ridges lie east of the main ridge at nearly the same elevation (Fig. 8). However, their surface texture differs considerably from the main ridge, the cobbles being much less rounded, and consisting of a greater variety of less resistant rock types. They also differ in that they occur only to the north of the lake, and do not cross the valley. The lake surface lies $4-5 \mathrm{~m}$ below the top of the ridges. We recently cored the lake-bottom sediments, and found a maximum water depth of $7.5 \mathrm{~m}$ and a sediment thickness of nearly $5 \mathrm{~m}$. Thus, the basin floor is $16-18 \mathrm{~m}$ below the top of the ridges. The field interpretation of the cores was that the entire sequence is lacustrine, starting with laminated clastic sediments at the bottom, and with increasing organic content upwards. It seems impossible to envisage that this basin was not filled with marine and lagoonal sediments, if it was open during deposition of the beach ridges. We therefore assume that a glacier tongue occupied the lake basin

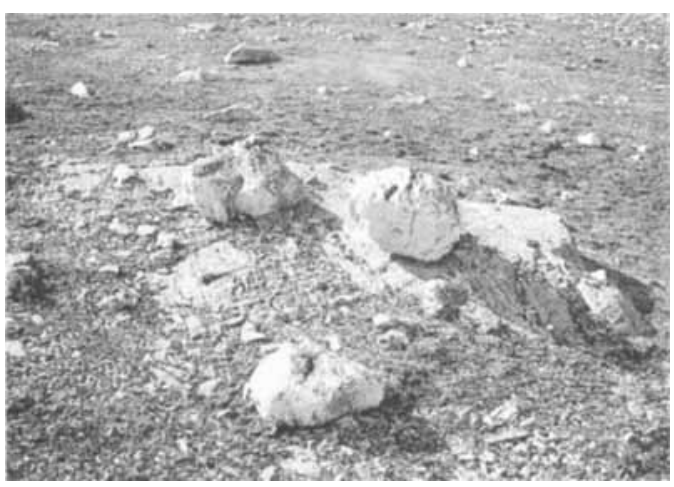

Fig. 7. Striated bedrock with undisturbed cobbles and boulders immediately above beach $\mathrm{C}$ at the mouth of Orustdalen, suggesting that this is the marine limit in the area. 
when the eastern ridges were formed, probably also during formation of the damming ridge. This interpretation is supported by the size of the outlet channel at the north end of the lake, which appears too large for the size of the drainage area, and thus might have been the outlet of the glacial river. There is probably very little time difference in the formation of the two ridges.

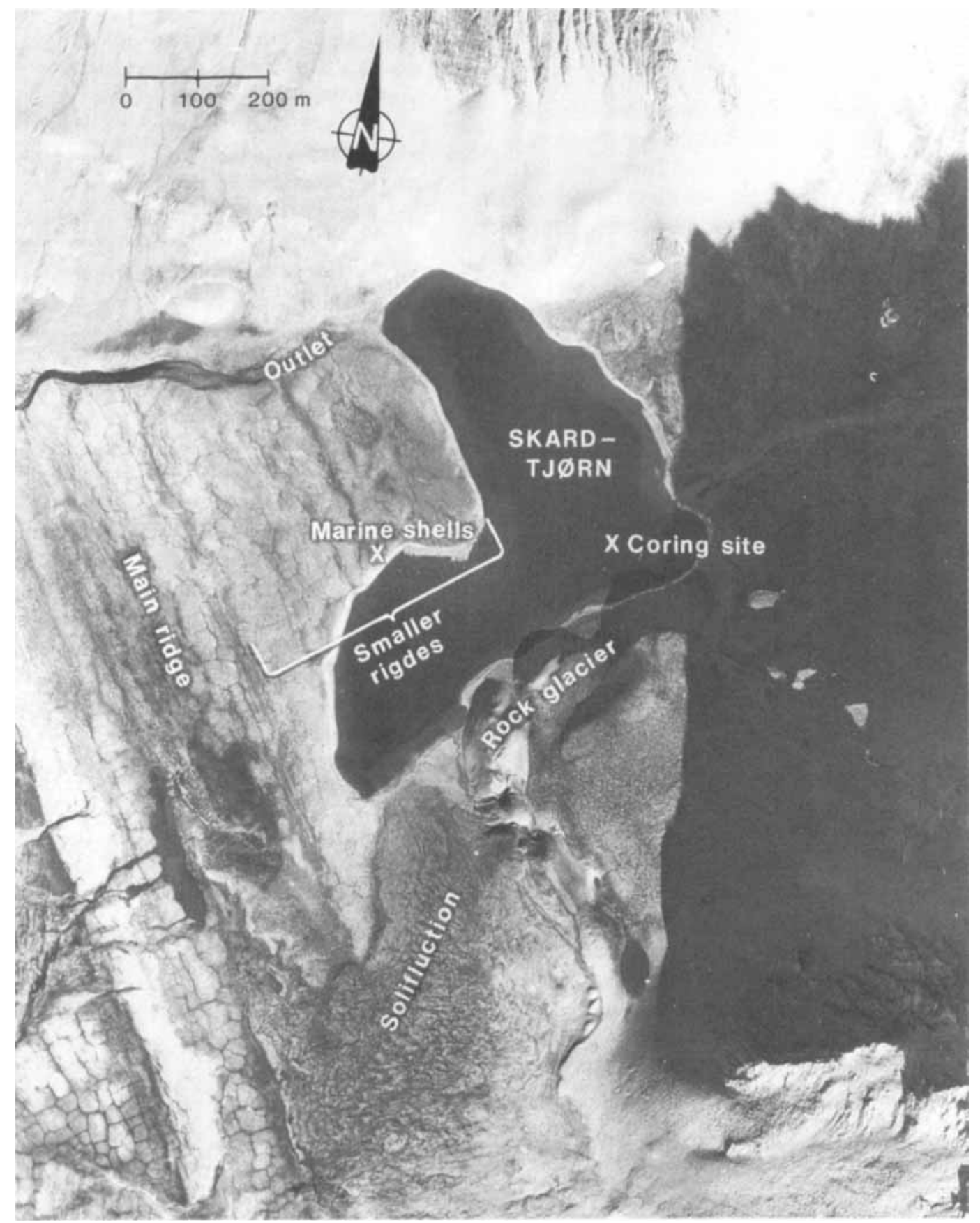

Fig. 8. Vertical air photo of Tjørnskardet with Skardtjørna. The two beach ridge systems of level C (see text) are seen to the left of the lake. Photo: Norsk Polarinstitutt \$69 2444. 
Within the area of the eastern ridges (Fig. 8), we found fragments of Hiatella arctica and $M y a$ truncata, radiocarbon dated to $38,400 \pm 650$ ( $\mathrm{T}-4863)$, which might represent a finite or infinite age. The shells were found in sandy, silty sediments that were brought to the surface by frost processes. It seems clear that the shells stratigraphically underlie the ridges, and from the interpretation of the ridges and the basin presented above, we assume they are considerably older than the ridges.

\section{Griegdalen}

The highest shoreline in Griegdalen was levelled to about $64 \mathrm{~m}$ a.s.l., and it lies close to the mountain slope. It is dissected by small streams, and conditions have not been favourable for formation and preservation of any possibly higher beaches at this site. Parts of the beach ridge have larger cobbles on the surface than the lower lying ridges. A pit was dug exposing gravel with some cobbles and small shell fragments.

\section{Måseneset}

At Måseneset (Fig. 1) Mangerud et al. (1984, 1985) suggested a lower marine limit than west of Akseløya and interpreted this as a possible ice front position at $11,000-10,500$ years B.P. However, reinvestigation of the area revealed sorted littoral gravel overlain by solifluction deposits up to a minimum of $73 \mathrm{~m}$ a.s.l. in a gully $1 \mathrm{~km}$ east of Måseneset. The littoral sediments can be traced all the way from sea level, and even though the bed is undated it might represent the eastward continuation of the 11,000-year-old shoreline west of Akseløya.

\section{The age of the marine limit}

Based on the observations at the mouth of Orustdalen and Ytterdalen, we consider the $64 \mathrm{~m}$ level to be the marine limit in the area. The age of the level is defined by shell dates of $11,020 \pm 110$ (T-4865) and 10,840 \pm 110 (T-5995) in Ytterdalen, which average slightly younger than 11,000 years. South of Bellsund we have obtained radiocarbon dates of 12,600 and 12,800 years B.P. on shells in a marine clay $18 \mathrm{~m}$ a.s.l. The corresponding sea level is unknown, but the clay must have been deposited at some depth, and the area must certainly have been deglaciated shortly after 13,000 years B.P.

\section{The marine limit - transgression or deglaciation}

Along the western coast of Spitsbergen to the north of Isfjorden (Fig. 1), pre-Late Weichselian shorelines undisturbed by glaciers (Salvigsen 1977; Miller 1982; Forman et al. 1987), demonstrate that the area was ice free a long period before the formation of the shoreline corresponding to level $\mathrm{C}$. In this area a transgression is postulated (Boulton 1979; Miller 1982), supposedly starting from low eustatic sea level stand at 18 to $20 \mathrm{ka}$. The normal situation in glacioisostatically depressed areas, however, is formation of the marine limit at the time the glacier left the site.

In the main valleys in our study area (Orustdalen, Ytterdalen and Linnédalen, Fig. 4), the pattern of well-preserved glacial striae strongly suggests that Late Weichselian ice lobes flowed out from the valleys. The absence of pre-Late Weichselian sediments or shorelines on the gentle valley floors and slopes also presents a strong argument for a Late Weichselian glacial erosion. We cannot exactly date the deglaciation of the valley lobes, but we can state that they were gone by the formation of level $\mathrm{C}$ about 11,000 years B.P.

Shoreline $\mathrm{C}$ can be traced along the entire coast (Fig. 4) and also across the valleys. This strongly suggests a synchronous formation, and thus it post-dates any glaciers including the valley lobes. The only exception is at Skardtjorn, where the main shoreline $C$ passes outside the postulated contemporaneous icelobe. This is the only available relative date of the deglaciation of the valley lobes. Such a synchronous formation suggests a transgression up to marine limit for the entire coast. Our observations inside the limits of the glacier lobes at Orustdalen (Fig. 7) give a maximum elevation of $64 \mathrm{~m}$ a.s.l. for this transgression.

We conclude that level $\mathrm{C}$ was formed during a transgression after the deglaciation of the valley lobes or by a transgression followed by a standstill in the relative sea level. The latter is 
indicated by the dates of 12.6 to $12.8 \mathrm{ka}$ at the south coast of Bellsund, and the curve by Forman et al. (1987).

\section{Beach level B}

The well-developed shoreline B can be traced all along Nordenskiöldkysten (Figs. 2, 3 and 4), approximately parallel to the marine limit (level C) terrace. The ridge is generally $50-60 \mathrm{~m}$ wide, has a relief of $1-2 \mathrm{~m}$, and is composed of both vegetation covered and exposed well-drained sandy gravel (Fig. 9). For large stretches, especially south of Orustdalen, it is considerably larger than shoreline $C$. The crest of the ridge has been levelled to 52 and $50 \mathrm{~m}$ a.s.l., south and west of the mouth of Ytterdalen, respectively, and $51 \mathrm{~m}$ a.s.l. west of Griegdalen, $25 \mathrm{~km}$ farther to the north.

At the mouth of Ytterdalen thick well-preserved Hiatella arctica in frost sorted-sediments at 50.9 m a.s.l. yielded $10.600 \pm 130$ years B.P. (T-5410). Immediately south of Orustdalen, shell fragments from a section cut by the fourth creek from the mouth of the valley, yielded a date of 20,060 \pm 210 (T-4864). After radiocarbon dating, amino acid analysis of several fragments confirms that this is a mixture of post-glacial and pre-Late Weichselian shells. This large beach ridge indicates a reduced rate of regression, or a transgression, around 10,600 to 10,000 years ago.

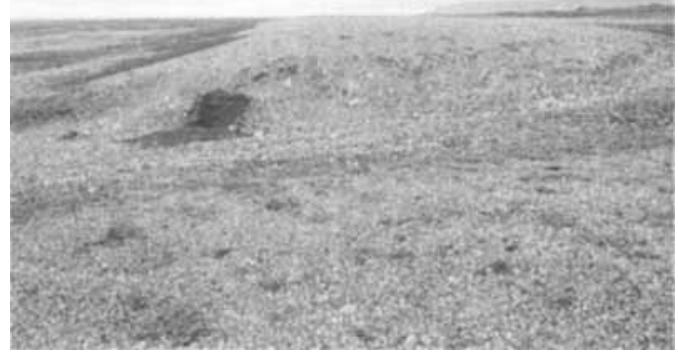

Fig. 9. Beach B, immediately south of Orustdalen, viewed towards the north, $3 \mathrm{~km}$ north of the 20,060-year date (T-4864). The weak ridge morphology is typical for this level along the coast.

\section{Beach level A}

The most dominant shoreline feature in the area is the large beach ridge sub-parellel to the present coast line (Figs. 2 and 4). Elevations of the crest of the ridge are $12.1 \mathrm{~m}$ a.s.l., south of Ytterdalen, and $10.8 \mathrm{~m}$ a.s.l., west of Griegdalen. The ridge is nearly continuous along the coast (Fig. 4), and has a major impact on drainage pattern and lake distribution. The formation of bogs behind the ridge led to the designation the 'green beach ridge series' (Stäblein 1978).

A whalebone buried in the top sediments of the beach ridge east of Ytterdalselva yielded $7,950 \pm 120$ years B.P. (T-5665), while a $35 \times 3$ $\mathrm{cm}$ piece of Picea sp., found immediately behind the ridge but associated with its sediments at Griegbekken, yielded $7,770 \pm 110$ years B.P. (T-5271). Situated stratigraphically in the upper part of the ridge, these dates should pre-date the formation of the ridge itself. However, some hundred metres from the first date, more than ten whale rib fragments were found buried in littoral sediments at $12.5 \mathrm{~m}$ a.s.l., well behind and above the ridge. One of them is dated to $7,760 \pm 110$ years B.P. (T-6221) and thus gives a maximum age for the formation of the ridge. We therefore assume that the described bone and wood in the ridge originally were deposited during the regression, but redeposited and embedded in the sediments by the subsequent transgression which formed the ridge.

\section{The Kleivdalsbekken section}

$280 \mathrm{~m}$ from the sea, Kleivdalsbekken (Fig. 4) cuts through a suite of raised beaches. A section along the southern bank lies $140 \mathrm{~m}$ seaward of the well-developed beach ridge $A$. The section is in a weakly developed beach ridge, $10.6 \mathrm{~m}$ a.s.I. Fig. 10 shows the $2.5 \mathrm{~m}$ high section where thin layers of seaweed are buried below more than $2 \mathrm{~m}$ of sand and gravel dipping at low angles towards the coast. The sediment is mainly well-sorted open structure gravel and coarse sand, forming discontinuous beds which are interfingering and wedging out.

The seaweed is found mainly as a more or less continuous, 2 to $5 \mathrm{~cm}$ thick layer that was exposed for more than $7 \mathrm{~m}$. A similar, but discontinuous 0.5 to $1 \mathrm{~cm}$ thick layer was found 10 to 20 


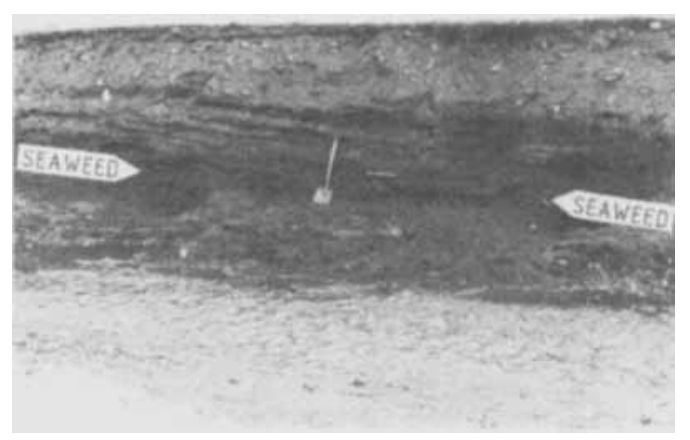

Fig. 10. The section at Kleivdalsbekken showing layers of seaweed buried by sand and gravel, interpreted to have been deposited during a transgression. The shovel is $1 \mathrm{~m}$ long.

$\mathrm{cm}$ higher up. The lowermost layer is dated to $6,250 \pm 60$ (T-5406). The layer is very compact and contains macrofossils of seaweed identified as Fucus and Sphacelaria (Jan Rueness, pers. comm. 1983). There are also remains of terrestrial plants, bird feathers, fishes etc., strongly indicating that this is seawrack deposited on the shore. Along such a relatively high energy coast, deposition of light-weight material on the sea floor is not likely to occur, and also along the presentday beach seawrack piles are found above the high tide mark. Thus we interpret the organic matter to have been deposited immediately above the contemporaneous sea level.

With such a depositional model, the thick sand and gravel beds above the organic layer can be explained only by a subsequent transgression. As the section is situated on the sea side of the beach ridge $A$, the simplest model would be to assume that this is a transgression culminating with the deposition of the ridge. This interpretation is supported by the significantly younger age $(5,210 \pm 90$ years B.P., T-5407) of a whalebone found in a beach at a higher elevation than the seaweed layer.

\section{The shoreline displacement curve}

A shoreline displacement curve for the Ytterdalen area (Fig. 11) is based upon a series of datings (Table 1, Fig. 12). mainly of whalebones. No whalebone or driftwood has been found above
$30 \mathrm{~m}$ a.s.l., which presents a problem in the determination of the older part of the curve. The reason for the lack of whalebones older than 9,100 years is hard to understand, as $12,000-13,000$ year-old bones are reported farther north from western Spitsbergen (Forman et al. 1985). A better altitude coverage of dateable matter would not necessarily give a more accurate curve, because, despite low standard deviations, the radiocarbon method gives too poor a resolution relative to the fast regression in this time interval.

\section{$11,000-10,000$ years}

After formation of the beach at the marine limit at $64 \mathrm{~m}$ a.s.l., the sea level dropped rapidly to beach level $B$ about $50 \mathrm{~m}$ a.s.l. This distinct level must have been formed by either a sea level standstill, or a transgression. However, there was only a short time available for the sea level to drop more than $14 \mathrm{~m}$ and then rise again to level $B$. Therefore, we conclude that there was no time

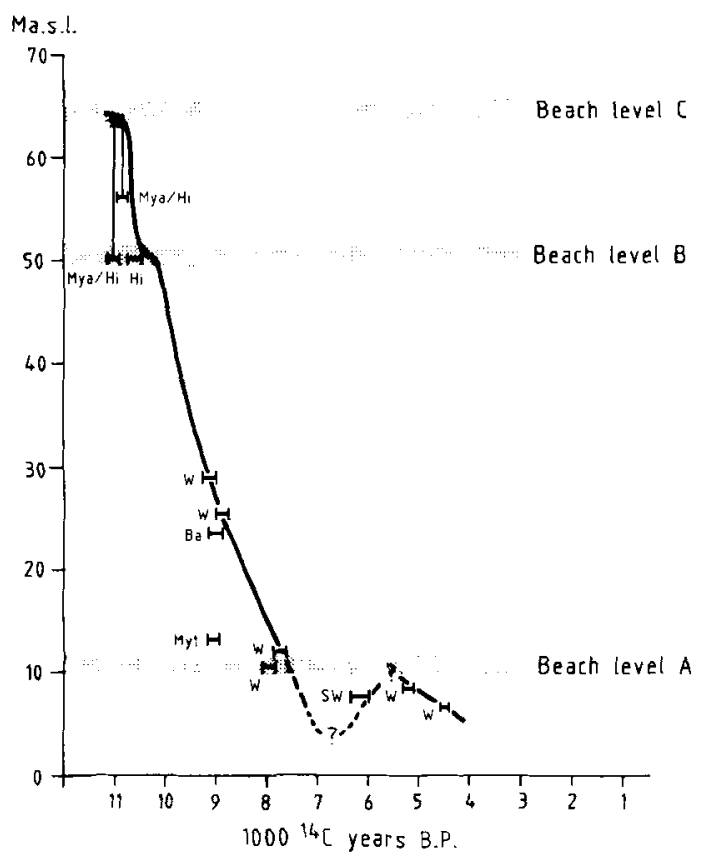

Fig. 11. Shoreline displacement curve for the Ytterdalen area. The shaded beach levels are very distinct, morphological units that can be traced al! along Nordenskiöldkysten (Fig. 3). $\mathrm{W}=$ whalebone, $\mathrm{SW}=$ seaweed, $\mathrm{Ba}=$ Balanus sp., Myt = Mytilus edulis, $\mathrm{Mya} / \mathrm{Hi}$ $=$ fragments of Mya truncata and Hiatella arctica. 


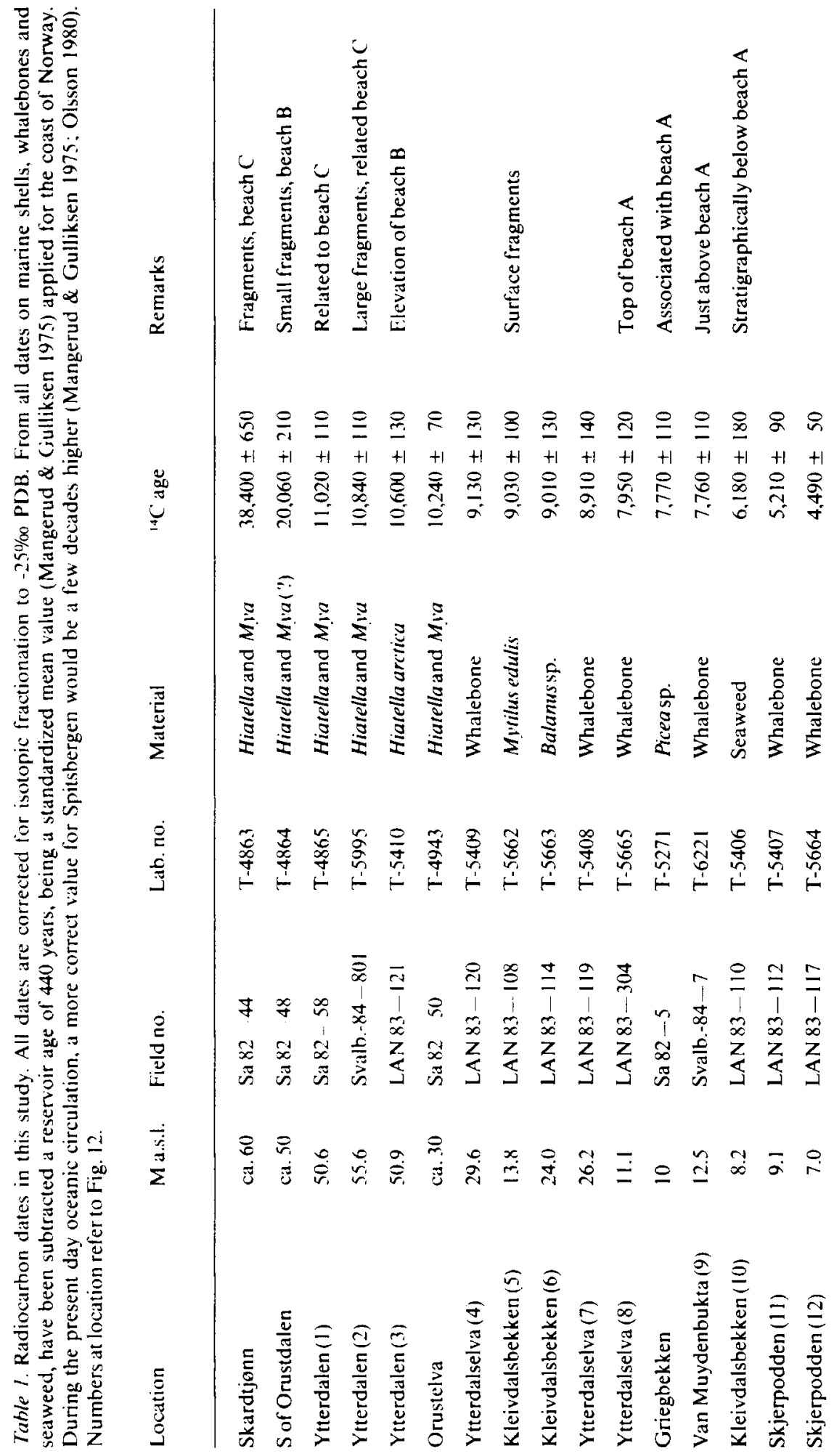




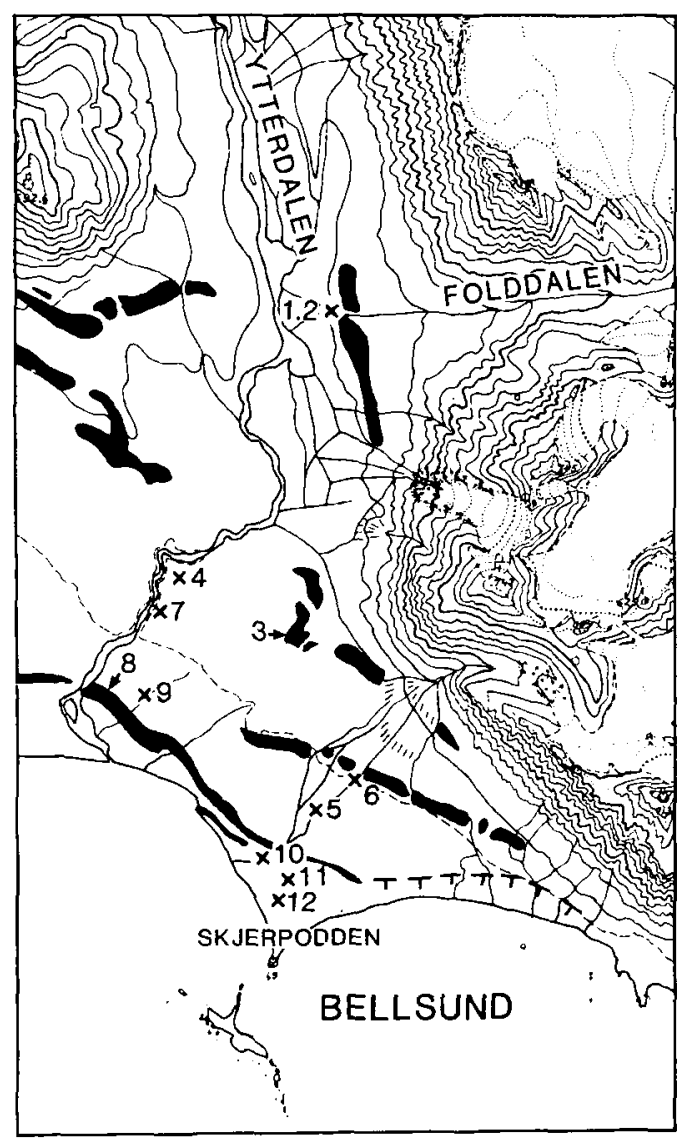

Fig. 12. Location of radiocarbon dates in the Ytterdalen area. All numbers refer to Table 1. Locations of dates outside this map are given separately or in the text.

for a major transgression, but there existed a near equilibrium in isostatic rebound versus eustatic sea level rise during the formation of beach $B$ $10,000-10,500$ years ago. Beach $B$ is dated by correlation with shells dated to $10,600 \pm 130$ (T-5410), but the dated sediments' exact relationship to the sea level is not well established and the date is considered a maximum age for beach B. At 9,130 years B.P. the sea level was as low as $19 \mathrm{~m}$, and therefore, given the altitude of $50 \mathrm{~m}$ a.s.l., an age of $10,000-10,600$ years is favoured for beach $B$.

\section{$10,000-8,000$ years}

Within 2,000 years the sea level dropped almost $40 \mathrm{~m}$, giving regression rates spanning from 2.2 to $1.2 \mathrm{~m} / 100$ years. A date on whalebone of 7,760 \pm 110 years B.P. (T-6221), carried out on one of more than ten rib fragments partly buried in littoral sediments within a small area just above beach $A$, is used to determine the trend of the curve.

\section{$8,000-4,000$ years}

This period is dominated by a Holocene transgression (Fig. 11). We have not been able to determine the regression minimum previous to the transgression. Extrapolation of the slowly decelerating regression rates prior to 8,000 B.P. years suggests that the regression reached $3-5 \mathrm{~m}$ a.s.l. (Fig. 11). The simplest model is to assume a transgression up to beach A, but we cannot prove that this time span did not include a more complex sequence of sea level oscillations.

Indications of a transgression in this time span on the west coast of Svalbard are reported from near Ny Alesund (Forman et al. 1987; Héquette 1986), and north of Isfjorden (Salvigsen unpublished). Most of the published shoreline displacement curves from Svalbard have been based exclusively on dates on whalebones, driftwood and shells from surface sediments, and they show no transgressions, e.g., the curve from Kapp Linné (Schytt et al. 1968). Using this method, the low sea level stands prior to transgressions can not be observed because dateable matter would either be buried or moved upward by the transgressing sea. Therefore, the lack of exposed stratigraphic sections is one of the main hindrances to detect transgressions. However, stratigraphic evidence of Holocene transgressions has been known for years on the islands to the east of Spitsbergen. Feyling-Hanssen (1965) described a layer containing terrestrial plant remains interbedded with marine sediments at Barentsøya. The plant remains were dated to $6,000 \pm 400$ years B.P., which is a maximum age for overlying sediments and the corresponding transgression. Hyvärinen (1969) made a similar conclusion by dating of lagoonal sediments in a lake core from Nordaustlandet (Fig. 1). There, the salt-water intrusion was dated to $5,550 \pm 140$ years B.P., and, as this was a lagoonal environment, it must also be an approximate date of the peak of the transgression.

Indications of a transgression can also be ob- 
served in some of the published shoreline displacement curves. From Svartknausflya, on Nordaustlandet, Salvigsen (1978) showed a decrease in regression rate for the period 7,500-5,500 years ago, followed by an increase during the next 2,000 years. He also pointed to the remarkable absence of whalebone and driftwood from the period between 7,500 and 6,300 years, which may have been the result of a rising sea level.

To determine a possible systematic change in regression rates during the critical period, we have calculated rates for every 500 years from several published curves from Svalbard. Even though all the shoreline displacement curves have an asymptotic shape, the plot of the regression rates (Fig. 13) shows both stability and a slight rise in the rates for the period from 7,000 to 3,000 years ago.

In East Greenland, Hjort (1973) demonstrated the Vega transgression culminating at 5,600 years B.P. He has later (Hjort 1981) pointed to the contemporaneous formation of distinct shorelines in Svalbard, Arctic Canada, and the Tapes transgression in Scandinavia. However, Kaland (1984) concluded that the Tapes transgression maximum would be delayed from the inner to the outer parts of Norway. At the Norwegian western coast, the Tapes transgression maximum of around $10 \mathrm{~m}$ a.s.l. was reached around 6,000

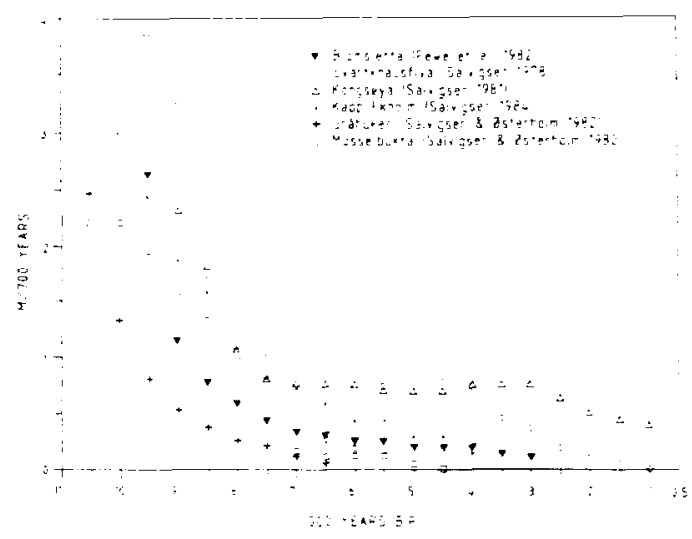

Fig. 13. Sea level regression rates calculated from published shoreline displacement curves. The rates are determined for every 500 years averaging over 1,000 years. years B.P. (Kaland 1984; Bjerck 1982; Hald \& Vorren 1983; Møller 1986), similar to the dates obtained in Svalbard.

\section{Isobases and the Late Weichselian glaciation}

The only published isobase maps are the maps of the postulated 6,500-year pumice level (Schytt et al. 1968), and the 9,000-year level (Boulton et al. 1982). Construction of the isobases, particularly the oldest ones, should reflect the distribution of the glacial ice that caused the rebound. So, we have calculated the oldest isobases, i.e. $11,000-10,000$ years B.P., in the study area. At the mouth of Griegdalen (Fig. 4), beach B is at $51 \mathrm{~m}$ a.s.l. and beach $\mathrm{C}$ at $64 \mathrm{~m}$ a.s.l. Corresponding elevations at Folddalen for beach $C$, and west of Ytterdalen for beach B suggests a direction of $150^{\circ}$ and $155^{\circ}$ for the isobases. Because the direction of the isobases may vary a little between the two levels, we preliminarily assume a direction of about $150^{\circ}$ for both. Considering the problems of determining precisely the sea level which corresponds with the beach ridges, this direction is a good approximation. This implies that the $11,000-10,000$ years B.P. isobase direction is sub-parallel to beach $B$ and $C$ along Nordenskiöldkysten.

When compared with western Norway, a marine limit of $64 \mathrm{~m}$ a.s.l. suggests an isostatic depression that requires a proximity to an ice sheet. We have earlier (Mangerud et al. 1984, 1985; Elgersma \& Helliksen 1986) stated that the marine limit in Van Mijenfjorden lies at lower altitudes and is younger than the 11,000-year old beach $C$, even though in this paper we have maintained that beach $\mathrm{C}$ probably continues a short distance to the east of Akseløya. Our main conclusion still is that a fjord glacier occupied Van Mijenfjorden when beach $\mathrm{C}$ was formed along the west coast of Spitsbergen. The finding of a Late Weichselian till deposited by a glacier which flowed into Bellsund from the south supports the conclusion of a considerable glaciation (Landvik 1986). This disproves any model of a very limited Late Weichselian glaciation on Spitsbergen (Boulton 1979; Boulton et al. 1982; Troitsky et al. 1979).

The first rapid emergence due to rebound 
caused by deglaciation was interrupted around $10,600-10,000$ years B.P. during the formation of beach $B$. This corresponds in time with the deposition of a glaciofluvial delta at Måseneset (Fig. 1) (partly described by Elgersma \& Helliksen 1986). The delta was dated to $10,230 \pm$ 140 years B.P. (T-5273), on in situ mollusks in the foreset beds. In addition, a glacier readvance in Bromelldalen, a tributary to Van Mijenfjorden, was bracketed between 10,500 and 10,100 years B.P. (Mangerud et al. 1985; Elgersma \& Helliksen 1986). Therefore, we conclude that the standstill or small transgression that caused the formation of the distinct shoreline B reflects a growth of the glaciers in Svalbard during the Younger Dryas.

The pattern, with three suites of morphologically distinct shorelines, is similar to the pattern on much of the coast of Norway where unconsolidated sediments were available for littoral processes (e.g. for northern Norway: Marthinussen 1960; Sollid et al. 1973; Andersen 1968; for southern Norway: Andersen 1960; Reite 1967; Thomsen 1982). As discussed above, the lower shoreline was formed during the Tapes transgression. The second line is of Younger Dryas age, and as Lie et al. (1983) demonstrated in More (western Norway) where it is a major feature, this was formed during a period with relative standstill of the sea level. In the southern part of western Norway Anundsen (1985) has demonstrated that it was formed during a Younger Dryas transgression.

The broad similarities in the shoreline patterns, especially the Younger Dryas lines, if correctly interpreted, also suggest greater similarities in the glacial histories between Scandinavia and Svalbard than assumed earlier.

Acknowledgements. - Anne Elgersma, Nils Flakstad, Ida Lonne and Helge Nesteby assisted during various stages of the field work. The drawings were made by Jane Ellingsen and Ellen Irgens. Radiocarbon dates were performed by the Laboratory of Radiological Dating (Trondheim) under the supervision of Reidar Nydal and Steinar Gulliksen, and amino acid analyses were done by Magne Bolstad and Hans-Petter Sejrup at the Amino Acid Laboratory at the University of Bergen. Leif M. Paulssen and Jan Rueness identified the driftwood and seaweed, respectively. John R. Reid Jr. improved the English. The reviewers, Bjorn G. Andersen and Svend Funder also suggested several improvements. Logistic support was provided by
Norsk Polarinstitutt, and the work was financially supported by the Norwegian Council for Science and Humanities (NAVF), Statoil, Norsk Polarinstitutt and the University of Bergen. The manuscript has profited from unpublished work in adjacent areas by the students M. Bolstad, A. Elgersma, D. Helliksen, A.K. Lycke, I. Lonne and T. Sandahl (University of Bergen) who have taken part in the co-operate project between our two institutions. To all these persons and institutions we proffer our sincere thanks.

\section{References}

Andersen, B.G. 1960: Sørlandet i sen- og postglasial tid. Nor. geol. unders. 210, 1-142.

Andersen, B.G. 1968: Glacial geology of western Troms, North Norway. Nor. geol. unders. 256. $1-160$.

Andersen, B.G. 1981: Late Weichselian ice sheets in Eurasia and Greenland. Pp. 1-65 in Denton G.H. \& Hughes, T.J. (eds.): The last great ice sheets. John Wiley \& Sons, New York.

Anundsen, K. 1985: Changes in shore-level and icefront position in Late Weichsel and Holocene, southern Norway. Nor. geogr. Tidsskr. 39, 205-225.

Bjerck, H.B. 1982: Archaeological and radiocarbon dating of the Holocene transgression maximum (Tapes) on Skuløy, Sunnmore, western Norway. Nor. Geol. Tidsskr. 62, 87-93.

Boulton, G.S. 1979: Glacial history of the Spitsbergen archipelago and the problem of a Barents Shelf ice sheet. Boreas 8,31-57.

Boulton, G.S., Baldwin, C.T., Peacock, J.D., McCabe, A.M., Miller, G., Jarvis, J., Horsefield, B., Worsley, P., Eyles, N., Chroston, P.N., Day, T.E., Gibbard, P., Hare, P.E. \& von Brunn, V. 1982: A glacioisostatic facies model and amino acid stratigraphy for late Quaternary events in Spitsbergen and the Arctic. Nature 298, 437-441.

Elverhøi, A. \& Solheim, A. 1983: The Barents Sea ice sheet - a sedimentological discussion. Polar Research 1 n.s., 23-42.

Elgersma, A. \& Helliksen, D. 1986: Kvartargeologiske undersøkelser $i$ Van Mijenfjordområdet, Spitsbergen. Svalbard. Unpublished thesis, University of Bergen (two volumes).

Feyling-Hanssen, R.W. 1965: Shoreline displacement in central Vestspitsbergen and a marine section from the Holocene of Talavera on Barentsaya in Spitsbergen. Norsk Polarinst. Med. 93, 1-34.

Forman, S. \& Miller, G. 1984: Time-dependent soil morphologies and pedogenic processes on raised beaches, Brøggerhalvøya, Spitsbergen, Svalbard archipelago. Arctic and Alpine Research 16, $381-394$.

Forman, S.L., Mann, D.H. \& Miller, G.H. 1985: Late Weichselian and Holocene relative sea level history of Broggerhalvoya, Spitsbergen. P. 139 in 14th Arctic Workshop. Arctic Land-Sea Interactions. Abstracts. Bedford Institute of Oceanography, Dartmouth. 
Forman, S., Mann, D. \& Miller, G. 1987: Late Weichselian and Holocene relative sea level history of Broggerhalvoya, Spitsbergen. Quaternary Research 27. $41-50$.

Hald. M. \& Vorren. T.O. 1983: A shoreline displacement curve from the Tromso district, North Norway. Nor. Geol. Tidsskr. 63,103-- 110.

Hèquette, A. 1986: Morpho-sédimentologie et évolution de littoraux meubles en milieu Arctique. Péninsule de Brogger. Spitsberg nord-occidental. Unpublished thesis. Lniversité de Bretagne occidentale, Brest. 397 pp.

Hjelle, A., Lauritzen, O., Salvigsen, O. \& Winsnes, T.S. 1986: Geological map of Svalbard 1:100,000. Sheet Van Mijenfjorden. Temakart Nr. 2. Norsk Polarinstitutt, Oslo.

Hjort, C. 1973: The Vega Transgression. A hypsithermal event in Central East Greenland. Bull. geol. Soc. Denmark 22, 25-38.

Hjort. C. 1981: Present and Middle Flandrian coastal morphology in Northeast Greenland. Nor. geogr. Tidsskr. 35, 197- 207

Hyvärinen, H. 1969: Trullvatnet: A Flandrian stratigraphical site near Murchisonfjorden Nordaustlandet, Spitsbergen. Geogr. Annlr. 5lA.42-45.

Kaland, P.E. 1984: Holocene shore displacement and shorelines in Hordaland, western Norway. Boreas 13.89-260.

Landvik, J. 1986: Weichsel glasialkronologi på vestlige Svalbard. Geolognvtl 21,37

Lie, S.E.. Stabell, B. \& Mangerud, J. 1983: Diatom stratigraphy related to Late Weichselian sea-level changes in Sunnmore, Western Norway. Nor. geol. unders. $380.203-219$.

Liestol. O. 1962: Talus terraces in Arctic regions. Nor. Polarinst. Arb. 1961, 102-105.

Mangerud, J. \& Gulliksen, S. 1975: Apparent radiocarbon age of recent marine shells from Norway, Spitsbergen and Ellesmere 1sland. Quatemar. Research 5.263 -..273.

Mangerud, B. \& Berglund, B.E. 1978: The subdivision of the Quaternary in Norden: a discussion. Boreas $7.179-181$

Mangerud, J., Andersen, S.T., Berglund, B.E. \& Donner, J.J. 1974: Quaternary stratigraphy of Norden. a proposal for terminology and classification. Boreas 3, $109-128$.

Mangerud, J. \& Salvigsen, O. 1984: The Kapp Ekholm section, Billefjorden, Spitsbergen: a discussion. Bureas 13,155-158.

Mangerud, J., Elgersma, A., Helliksen, D., Landvik, J. \& Salvigsen, O. 1984: The Late Weichselian (25-10 ka B.P.) glacial maximum in Isfjorden and Van Mijenfjorden, Spitsbergen, Svalbard. Pp. 67-68 in Abstracts 13th Annual Arctic Workshop. INSTAAR. Univ. of Colorado, Boulder.

Mangerud, J., Elgersma, A., Helliksen, D., Landvik. J.
\& Salvigsen, O. 1985: The Late Weichselian glaciation in Isfjorden and Van Mijenfjorden, Svalbard. Pp. 16-17 in Sediments and Climate in the Arctic. Rapport, Voksenåsendagene 9.-11. april 1984.

Marthinussen, M. 1960: Coast and fjord areas of Finnmark. With remarks on some other districts. In Holtedahl O. (ed.): Geology of Norway. Nor. geol. unders. 208.416-434.

Miller, G.H. 1982: Quaternary depositional episodes, western Spitsbergen, Norway: aminostratigraphy and glacial history. Arctic and Alpine Research 14, $321-340$.

Moller, J.J. 1986: Holocene transgression maximum about 6000 years BP at Ramså, Vesterålen, North Norway. Nor. geogr. Tidsskr. 40.77-84.

Ohta, Y. 1982: Morpho-tectonic studies around Svalbard and the northmost Atlantic. In Embry, A.F. \& Balkwill, H.R. (eds.): Arctic geology and geophysics. Can. Soc. Petrol. Geol. Mem. 8, 415-429.

Olsson, I.U. 1980: Content of ${ }^{14} \mathrm{C}$ in marine mammals from northern Europe. Radiocarbon 22,662-675.

Reite, A.J. 1967: Lokalglasiasjon på Sunnmøre. Nor. geol. unders. 147, 262-287.

Salvigsen, O. 1977: Radiocarbon datings and the extension of the Weichselian ice sheet in Svalbard. Nor. Polarinst. Arb. 1976. 209-224.

Salvigsen, O. 1978: Holocene emergence and finds of pumice, whalebones, and driftwood at Svartknausflya, Nordaustlandet. Nor. Polarinst. Arb. 1977. $217-228$.

Salvigsen, O. 1981: Radiocarbon dated raised beaches in Kong Karls Land, Svalbard, and their consequences for the glacial history of the Barents Sea area. Geogr. Annir. 63A, 283-291.

Salvigsen, O. \& Nydal, R. 1981: The Weichselian glaciation in Svalbard before 15,000 B.P. Boreas $10.433-446$.

Sandahl, T.J. 1986: Kvartargeologiske undersøkelser $i$ områder Lewinodden - Kapp Starostin - Linnévannet ytre Isfjorden, Svalbard. Unpublished thesis, University of Bergen (two volumes).

Schytt, V., Hoppe, G., Blake Jr., W. \& Grosswald, M.G. 1986: The extent of the Würm glaciation in the European arctic. Int. Ass. Sci. Hydrol. 79, 207-216.

Sollid, J.L., Andersen, S., Hamre. N., Kjeldsen, O., Salvigsen, O., Sturod, S., Tveitå, T. \& Wilhelmsen, A. 1973: Deglaciation of Finnmark, North Norway. Nor. geogr. Tidsskr. 27.233-325.

Stäblein, G. 1978: Extent and regional differentiation of glacioisostatic shoreline variation in Spitsbergen. Polarforschung 48, 170-180.

Thomsen, H. 1982: Late Weichselian shore-line displacement on Nord-Jæren, south-west Norway. Geol. Fören. Stockh. Förhandl. 103,447-468.

Troitsky, L. Punning, J.-M., Hütt, G. \& Rajamäe, R. 1979: Pleistocene chronology of Spitsbergen. Boreas $8,401-407$. 